\title{
LA Grade C
}

National Cancer Institute

\section{Source}

National Cancer Institute. LA Grade C. NCI Thesaurus. Code C62426.

Mucosal breaks that extend between the tops of two or more mucosal folds, but which involve less than $75 \%$ of the esophageal circumference. 